\title{
Threshold Effect of Capital Structure on Firm Value: Evidence from Seafood Processing Enterprises in the South Central Region of Vietnam
}

\author{
Nguyen Thanh Cuong \\ Faculty of Accounting and Finance, Nha Trang University, VietNam
}

\begin{abstract}
The purpose of this paper is to investigate whether there is an optimal capital structure at which point firm is able to maximize its value. The author employ an advanced panel threshold regression estimation developed in 1999 by Hansen that will indicate whether there are positive and negative impacts of capital structure on firm value. The author has used data of among 90 unlisted Seafood Processing Enterprises in the South Central region of Vietnam (SEASCRs) during 2005-2011 period. The author has used book value of equity plus long- term debt (BVE) and return on equity (ROE) as surrogate for firm value and book value of total debt to total assets (TD/TA) as surrogate for capital structure and as the threshold variable.

The empirical results strongly indicate that triple threshold effect exists between debt ratio and firm value when BVE is selected to proxy firm value. However, when ROE is selected to proxy firm value, the result shows that there exists double thresholds effect between debt ratio and firm value. From these results, the author may conclude that the relationship between capital structure and firm value has a nonlinear relationship represents an convex Parapol shape. In addition, the findings suggest implications for SEASCRs on flexible usage of financial leverage. Specifically, SEASCRs should not use loans over 57.39\%. To ensure and enhance the firm value, the scope of the optimal debt ratio should be less than $57.39 \%$.
\end{abstract}

Keywords: Capital Structure; Firm Value; Panel Threshold Regression Model; SEASCRs.

JEL code: C33; G32

C) 2014 Published by SSBFNET

\section{Introduction}

Since the 60 years, the relationship between capital structure and firm value has been the subject of considerable debate. The results of both theoretically and in empirical research formed three different perspectives on this relationship: (i) The capital structure is unrelated to firm value (Modigliani and Miller (1958), Phillips and Sipahioglu (2004), Walaa Wahid ElKelish (2007), Pornsit Jiraporn and Yixin Liu (2008)); (ii) The capital structure is related positive or negative to firm value (Modigliani and Miller (1963), Miller (1977), Myers and Majluf (1984), Joshua Abor (2005), R. Zeitun et al.(2007), Onaolapo et al.(2010), Ali Saeedi et al.(2011), Wenjuan Ruan et al.(2011), Nour Abu-Rub (2012), Abdul Ghafoor Khan (2012), Zuraidah Ahmad et al.(2012)). The results of these studies indicate that the enterprise value is a linear function of capital structure, means that the slope of the enterprise value is constant in all the different debt ratios. Means that regression functions are identical across all observations in a 
sample; (iii) There exists an optimal capital structure for each enterprise (Myers (1977, 1984), Feng-Li Lin (2007), Chien-Chung Nieh et al.(2008), Yu-Shu Cheng et al.(2010), Cuong and Canh (2012), Ahmad and Abdullah (2013)).

The South Central region of Vietnam stretches across 7 provinces and one coastal city, from Da Nang city to Binh Thuan province. This is the area where Seafood processing sector is the one of the most prominent sector of Vietnam that significantly contributes towards the economy in terms of creating employment, exports and its contribution in GDP. Characteristics of area's seafood processing enterprises are small-scale, newly-established, semi-manual labored, backward processing technology. The number of listed companies on the stock market is limited. Further, they present low profitability, high bankruptcy risk due to continuous natural disasters, output markets of numerous barriers, limited capital and so on. During 2010-2012, with the increase of interest rates, financial costs have significantly gone up in this years, resulting in decreasing profit of the firms, many businesses have closed and declared bankruptcy.

From the above practices, study the effect of capital structure on firm value for SEASCRs will help the enterprises making the decisions of enterprise capital restructuring more suitable. Specifically, how to use debt reasonably, in which case the increasing debt is effective, in which case the debt limit to reduce risk, reduce the risk of damage to enterprises. It is, therefore, of a particular, interest to investigate the relationship between capital structure and firm value in a sample of SEASCRs.

In this study, for the purpose of indicating the extent of capital structure, the debt will have a positive effect, increasing enterprise value; the extent of capital structure, the debt will have negative effects, reducing the value of the enterprise. This research applies the threshold regression model of Hansen (1999) to construct the threshold regression model to investigate the effect of capital structure on firm value for Seafood Processing Enterprises in the South Central Region of Vietnam.

The paper is divided into six sections. The next section reviews the results of previous theoretical and empirical research. The third section provides the sample data and the variables. The fourth section discusses the methodology. Section 5 discusses the empirical results, and the final section summarizes the key findings and implications.

\section{Literature Review}

The capital structure of a firm concerns the mixture of debt and equity the firm uses in its operation. The relationship between capital structure and firm value has been the subject of considerable debate, both theoretically and in empirical research. Through out the literature, debates have focused on whether there is an optimum capital structure for an individual firm or whether the proportion or level of debt usage is irrelevant or relevant to the firm's value.

\subsection{Theoretical Literature}

The debates on the relevance of capital structure to firm value has progressed from academic model to practical reality since Modigliani \& Miller's research (1958). In a frictionless and perfect markets world, the irrelevant capital structure of Modigliani and Miller (1958) argued that firm value was independent of firm capital structure, and there was no optimal capital structure for a specific firm. However, Modigliani and Miller's (1958) perfect market 
assumptions: such as no transaction costs, no taxes, symmetric information and identical borrowing rates, and risk free debt, were contradictory to the operations in the real world.

In their subsequent paper, Modigliani and Miller (1963) relaxed their assumption by incorporating corporate tax benefits as determinants of the capital structure of firms. The key feature of taxation is the recognition of interest as a tax-deductible expense. A firm that pays taxes receives a partially offsetting interest "tax-shield" in the nature of lower taxes paid. In other words, the firm value is increased through the use of debt in the capital structure, due to the tax deductibility of interest payments on debt. This is a tacit admission in which capital structure affects firm value. Consequently, as Modigliani and Miller (1963) proposed, firms should use as much debt capital as possible to maximize their value. In analogous to Modigliani and Miller's (1963) propositions, Miller (1977) incorporated both corporate taxes and personal taxes into his model. According to Miller (1977), the value of the firm depends on the relative level of each tax rate, compared with the other two. Miller (1977) indicated that relative level of each tax rate determines firm value, and that the gain from employing debt may be smaller than what was suggested in Modigliani and Miller (1963).

The pecking order theory proposed by Myers and Majluf (1984), suggests that there is a hierarchy of firm preferences with regard to the financing of their investments and that there is no well-defined target debt ratio. The conclusion drawn from the pecking order theory is that there is a hierarchy of firm preferences with respect to the financing of their investments. This theory suggests that firms finance their needs, initially by using internally generated funds, i.e. undistributed earnings, where there is no existence of information asymmetry, next by less risky debt if additional funds are needed and lastly by risky external equity issue to cover any remaining capital requirements. The order of preferences reflects relative costs of finance to vary between the different sources of finance. Therefore, the pecking order theory indicates a negative relationship between profitability and debt.

The static Trade-off theory was developed by Myers in 1977. Myers $(1977,1984)$ suggests that the optimal capital structure does exist. A value-maximizing firm will find an optimal capital structure by trading off benefits and costs of debt financing. Therefore, it values the company as the value of the firm if unlevered plus the present value of the tax shield minus the present value of bankruptcy and agency costs.

\subsection{Empirical Literature}

Table 1 shows the summary of the findings of previous authors related to the impact of capital structure on firm value. 
Table 1: Previous findings on the impact of capital structure on firm value

\begin{tabular}{|c|c|c|}
\hline Author & Findings & $\begin{array}{c}\begin{array}{c}\text { Countr } \\
\text { y/Mark } \\
\text { ets }\end{array} \\
\end{array}$ \\
\hline \multicolumn{3}{|c|}{ The capital structure is unrelated to firm value } \\
\hline $\begin{array}{l}\text { Phillips et } \\
\text { al. (2004) }\end{array}$ & $\begin{array}{l}\text { Empirical analysis revealed no significant relationship between the level of debt found in the capital structure } \\
\text { (TD/TA) and financial performance (Tobin's Q). }\end{array}$ & UK \\
\hline $\begin{array}{l}\text { Walaa } \\
\text { Wahid } \\
\text { ElKelish } \\
(2007) \\
\end{array}$ & $\begin{array}{l}\text { Findings suggest that debt to equity ratio (TD/TE) has no impact on firm value (measured according to the } \\
\text { Discounted Cash Flow model in perpetuity). }\end{array}$ & $\begin{array}{c}\text { United } \\
\text { Arab } \\
\text { Emirate } \\
\mathrm{s} \\
\end{array}$ \\
\hline $\begin{array}{l}\text { Pornsit } \\
\text { Jiraporn et } \\
\text { al. }(2008)\end{array}$ & $\begin{array}{l}\text { The results demonstrate no significant adverse impact on firm value (Tobin's Q, ROA) due to excess leverage } \\
\text { (TD/TA). }\end{array}$ & USA \\
\hline \multicolumn{3}{|c|}{ The capital structure is related positive or negative to firm value } \\
\hline $\begin{array}{l}\text { Joshua } \\
\text { Abor } \\
(2005)\end{array}$ & $\begin{array}{l}\text { Found a positive relationship between capital structure }(\mathrm{SD} / \mathrm{TA} \text {, TD/TA) and firm performance (ROE). } \\
\text { However, a negative relationship between capital structure (LD/TA) and ROE was found. }\end{array}$ & Ghana \\
\hline $\begin{array}{l}\text { R. Zeitun et } \\
\text { al.(2007) }\end{array}$ & $\begin{array}{l}\text { Found a negative relationship between capital structure (SD/TA, LD/TA, TD/TA) and corporate performance } \\
\text { (ROA, Tobin'Q). }\end{array}$ & Jordan \\
\hline $\begin{array}{l}\text { Onaolapo et } \\
\text { al. }(2010)\end{array}$ & Found a negative relationship between capital structure (TD/TA) and firm performance (ROA, ROE). & Nigeria \\
\hline $\begin{array}{l}\text { Ali Saeedi } \\
\text { et al. }(2011)\end{array}$ & $\begin{array}{l}\text { Findings suggest that firm performance (EPS, Tobin's Q is significantly and positively associated with capital } \\
\text { structure (SD/TA, LD/TA, TD/TA), while report a negative relation between capital structure and ROA. } \\
\text { Moreover, there is no significant relationship between ROE and capital structure. }\end{array}$ & Iran \\
\hline $\begin{array}{l}\text { Wenjuan } \\
\text { Ruan et } \\
\text { al. }(2011)\end{array}$ & $\begin{array}{l}\text { Found that managerial ownership negatively impacts the ratio of total debt to total assets and the ratio of total } \\
\text { debt to total assets negatively impacts firm value (Tobin's Q). }\end{array}$ & China \\
\hline $\begin{array}{l}\text { Nour Abu- } \\
\text { Rub (2012) }\end{array}$ & $\begin{array}{l}\text { Found a positive relationship between capital structure (SD/TA, LD/TA, TD/TA, TD/TE) and firm performance } \\
\text { (ROE, ROA, EPS, MBVR and Tobin's Q). }\end{array}$ & Palestin \\
\hline $\begin{array}{l}\text { Zuraidah } \\
\text { Ahmad et } \\
\text { al.(2012) }\end{array}$ & $\begin{array}{l}\text { Found a negative relationship between capital structure (SD/TA, TD/TA) and firm performance (ROE, ROA). } \\
\text { However, a positive relationship between capital structure (LD/TA) and ROE was found. }\end{array}$ & $\begin{array}{c}\text { Malaysi } \\
\text { a }\end{array}$ \\
\hline $\begin{array}{l}\text { Abdul } \\
\text { Ghafoor } \\
\text { Khan } \\
(2012)\end{array}$ & $\begin{array}{l}\text { Found a negative relationship between capital structure (SD/TA, TD/TA) and firm performance (ROA, Tobin's } \\
\text { Q). Moreover, there is no significant relationship between ROE and capital structure. }\end{array}$ & $\begin{array}{c}\text { Pakista } \\
n\end{array}$ \\
\hline \multicolumn{3}{|c|}{ There exists an optimal capital structure for each enterprise } \\
\hline $\begin{array}{l}\text { Feng-Li Lin } \\
(2007)\end{array}$ & $\begin{array}{l}\text { Found that the optimal range of debt ratio (TD/TA) between } 48.92 \% \text { and } 49.55 \% \text { that increases firm value. } \\
\text { (Tobin's Q). }\end{array}$ & Taiwan \\
\hline $\begin{array}{l}\text { Chien- } \\
\text { Chung Nieh } \\
\text { et al. } \\
(2008)\end{array}$ & $\begin{array}{l}\text { Found that the optimal range of debt ratio (TD/TA) between } 12.37 \% \text { and } 28.70 \% \text { that increases firm value } \\
\text { (ROE, EPS). }\end{array}$ & Taiwan \\
\hline $\begin{array}{l}\text { Yu-Shu } \\
\text { Cheng et al. } \\
(2010)\end{array}$ & Found that the optimal debt ratio (TD/TA) of less than $70,48 \%$ enhances firm value (ROE). & China \\
\hline $\begin{array}{l}\text { Cuong and } \\
\text { Canh } \\
(2012)\end{array}$ & Found that the optimal debt ratio (TD/TA) of less than $59.27 \%$ enhances firm value (ROE). & $\begin{array}{c}\text { Vietna } \\
\mathrm{m}\end{array}$ \\
\hline $\begin{array}{l}\text { Ahmad and } \\
\text { Abdullah } \\
\text { (2013) }\end{array}$ & $\begin{array}{l}\text { Found that the optimal leverage (ratio of total liabilities to total assets) of less than } 64.33 \% \text { that increases firm } \\
\text { value (ROE). }\end{array}$ & $\begin{array}{c}\text { Malaysi } \\
\text { a }\end{array}$ \\
\hline
\end{tabular}

Notes: $R O A=$ the return on assets; $R O E=$ return on equity; Tobin's $Q=($ Market value of equity + book value of debt)/ book value of assets; $M B V R=$ Market value of equity/Book value of equity; $E P S=$ net income/ outstanding shares; $S D / T A=$ short-term debt / total assets; LD/TA = Long-term debt $/$ total assets; TD/TA = total debt $/$ total assets; $T D / T E=$ Total debt $/$ total equity. 
In summary, there is no universal theory of the debt-equity choice. Different views have been put forward regarding the financing choice. This research applies the threshold regression model of Hansen (1999) to construct the threshold regression model to investigate the effect of capital structure on firm value for Seafood Processing Enterprises in the South Central Region of Vietnam.

\section{Data and Variables}

\subsection{Sample Description}

The sample of the study consists of 90 unlisted Seafood processing enterprises in the South Central region of Vietnam from 2005-2011. For some enterprises, collected data consists of balance sheets and annual business outcome reports. With the enterprises are collected across a period of 7 years, this study has 630 observations.

\subsection{Variables}

\subsubsection{Firm Value}

Firm value has been measured through the accounting and market based proxies i.e. ROA, ROE, MBVR, Tobin's Q and EPS by the previous studies. However, characteristics of Seafood processing enterprises in the South Central region of Vietnam are unlisted enterprises. The aforementioned argument suggests that the suitable firm value should be based on book value. This study has used book value of equity plus long- term debt supported by the studies of Samuel Antwi et al. (2012), OGBULU et al. (2012) and return on equity supported by the studies of Chien-Chung Nieh et al. (2008), Yu-Shu Cheng et al. (2010), Cuong and Canh (2012), Ahmad and Abdullah (2013) as proxy of firm value. The measurement of firm value defined as below:

\section{BVE $=$ Book Value of Equity + Long- term Debt \\ Book value of Earnings after taxes \\ ROE $=$ \\ Book value of Equity}

\subsubsection{Threshold and explanatory variables}

There are two categories of explanatory variables in my panel data and threshold regression model. One is the threshold variable, which is the key variable used to assess the optimal capital structure of a firm and to capture the threshold effect of debt on firm value. The threshold variable is a variable, when threshold variable is bigger or smaller than threshold value $(\gamma)$, the samples can be divided into two groups, which can be expressed in different slopes $\beta_{1}$ and $\beta_{2}$. The explanatory variable is a variable, reflecting its impact on the dependent variable. In the threshold regression model, explanatory variable impacts are not fixed but depends on the threshold value of the threshold variable. According to the "Trade-off Theory" of capital structure and the threshold regression model of Hansen (1999), the author assume that there exists an optimal capital structure for each Seafood Processing Enterprises in the South Central Region of Vietnam. 
Following Feng-Li Lin (2007), Chien-Chung Nieh et al. (2008), Yu-Shu Cheng et al. (2010), Cuong and Canh (2012), the author use total debt to total assets (TD/TA) to represent the capital structure. It is the explanatory variable and also the threshold variable. The measurement of capital structure defined as below:

\section{Book value of Total debt \\ TD/TA = \\ Book value of Total assets}

\subsubsection{Control variables}

On the basis of previous studies, two control variables are used in this study includes enterprise size and firm's growth. Following section will analyze interconnection between those variables relative to firm value.

Enterprise size (SIZE) is considered one determinant of firm value. Joshua Abor (2005) suggest that enterprises of higher size generally have higher profitability. This suggests a positive relationship between the control variable (enterprise size) and profitability. On the other hand, researches by Yu-Shu Cheng et al. (2010) suggest that enterprises of higher size generally have lower firm value. This would suggest a negative relationship between the control variable (firm size) and firm value. Regard to this variable, the author suggest that enterprise size might have either positive or negative relationship with firm value. To measure enterprise size, Yu-Shu Cheng et al. (2010), Cuong and Canh (2012) have used natural log of total asses to measure the firm size. This study has also used natural $\log$ of total assets as proxy of firm size as below:

\section{SIZE $=\operatorname{Ln}($ Book value of Total assets $)$}

Growth (SG) is considered to be a factor related to firm value. Joshua Abor (2005) suggest that enterprises of higher growth opportunities generally have higher profitability. Additionally, researches by Chien-Chung Nieh et al. (2008), Yu-Shu Cheng et al. (2010) suggest that enterprises of higher growth rate on operating sales generally have higher firm value. Regard to this variable, the author suggests a positive relationship between the control variable (growth) and firm value. To measure growth, previous studies have reported \% change in total assets and \% change in annual sales as measure of firm's growth rate. This study has used \% change in annual sales as measure of growth rate of sales supported by the studies of Yu-Shu Cheng et al. (2010), Cuong and Canh (2012). The measurement of growth ratio defined as below:

\section{Total Annual revenue (t) - Total Annual revenue (t-1) \\ SG $=\frac{\text { Total Annual revenue (t-1) }}{\text { Total Ant }}$}

\section{Research Methodologies}

According to the "Trade-off Theory" of capital structure, when debt ratio increases, the interest tax shield increases. However, on the other side, leverage related costs increase to offset the positive effect of debt ratio to the firm value. Thus, this paper aims at examining whether threshold effect exists between the capital structure and value. The author assume that there exists an optimal debt ratio, and try to use threshold model to estimate this ratio, which can capture 
the relationship between capital structure and firm value as well as help financial managers make decisions of enterprise capital structuring more suitably. This research applies the threshold regression model of Hansen (1999) and refer to the empirical study of Chien-Chung Nieh et al. (2008), Yu-Shu Cheng et al. (2010), Cuong and Canh (2012) to construct the panel threshold regression model to investigate the effect of capital structure on firm value for Seafood Processing Enterprises in the South Central Region of Vietnam. The author constructed the following single threshold model:

$$
\mathrm{FV}_{i t}= \begin{cases}\mu_{i}+\theta^{\prime} H_{i t}+\beta_{1}(\mathrm{TD} / \mathrm{TA})_{i t}+\varepsilon_{i t}, & \text { if }(\mathrm{TD} / \mathrm{TA})_{i t} \leq \gamma \\ \mu_{i}+\theta^{\prime} H_{i t}+\beta_{2}(\mathrm{TD} / \mathrm{TA})_{i t}+\varepsilon_{i t}, & \text { if }(\mathrm{TD} / \mathrm{TA})_{i t}>\gamma\end{cases}
$$

Where $\theta^{\prime}=\left(\theta_{1}, \theta_{2}\right)^{\prime}$ and $\mathrm{H}_{\mathrm{it}}=\left(\mathrm{SIZE}_{\mathrm{it}}, \mathrm{SG}_{\mathrm{it}}\right)^{\prime} .(\mathrm{TD} / \mathrm{TA})_{\mathrm{it}}$ is the explanatory variable and also the threshold variable; $\mathrm{FV}_{\text {it }}$ represents firm value $\left(\mathrm{ROE}_{\text {it }}\right.$ and $\mathrm{BVE}$ it $) ; \gamma$ is the hypothesized specific threshold value. $\theta_{1}, \theta_{2}$ represent the coefficient estimates of the control variables. $\mu_{\mathrm{i}}$ is a given fixed effect used to grasp the heterogeneity of different companies under different operating conditions; $\beta_{1}$ is the threshold coefficient when the threshold value is lower than $\gamma ; \beta_{2}$ is the threshold coefficient when the threshold value is higher than $\gamma$; Error item $\varepsilon_{\text {it }}$ must comply with the iid assumptions $\left(\mathrm{e}_{\mathrm{it}} \sim\right.$ iid $\left(0, \sigma^{2}\right)$ ), where the average is 0 , and variance is $\sigma^{2}$; i represents different firms and $t$ represents different periods.

For the estimation procedures, the author first eliminate the individual effect $\mu_{\mathrm{i}}$ using the "within Transformation" estimation techniques in the traditional fixed effect model of panel data. By using the ordinary least squares and minimizing the concentrated sum of squares of errors, $S_{1}(\gamma)$, the author can obtain the estimators of our threshold value and the residual variance, $\hat{\gamma}$ and $\widehat{\sigma}^{2}$, respectively.

For the testing procedures, first, the author have to go on to test the null hypothesis of no threshold effect, $\mathrm{H}_{0}: \beta_{1}=\beta_{2}$, which can be based on the likelihood ratio test: $\mathrm{F}_{1}=\left(\mathrm{S}_{0}-\mathrm{S}_{1}(\hat{\gamma})\right) / \widehat{\sigma}^{2}$, where $\mathrm{S}_{0}$ and $\mathrm{S}_{1}(\hat{\gamma})$ are sum of squared errors under null and alternative hypotheses, respectively. However, as the asymptotic distribution of $F_{1}$ is non-standard, the author use the procedure of bootstrap to construct the critical values and P-value.

Upon the existence of threshold effect, $\mathrm{H}_{0}: \beta_{1} \neq \beta_{2}$, the author should test for the asymptotic distribution of threshold estimate, $\mathrm{H}_{0}: \gamma=\gamma_{0}$, and adopt the likelihood ratio test: $\mathrm{LR}_{1}=\left(\mathrm{S}_{1}(\gamma)-\mathrm{S}_{1}(\hat{\gamma})\right) / \widehat{\sigma}^{2}$ with the asymptotic confidence intervals: $c(\alpha)=-2 \log (1-\sqrt{1-\alpha})$.

If there exist double thresholds, the model can be modified as:

$$
\mathrm{FV}_{i t}= \begin{cases}\mu_{i}+\theta^{\prime} H_{i t}+\beta_{1}(\mathrm{TD} / \mathrm{TA})_{i t}+\varepsilon_{i t}, & \text { if }(\mathrm{TD} / \mathrm{TA})_{i t} \leq \gamma_{1} \\ \mu_{i}+\theta^{\prime} H_{i t}+\beta_{2}(\mathrm{TD} / \mathrm{TA})_{i t}+\varepsilon_{i t}, & \text { if } \gamma_{1}<(\mathrm{TD} / \mathrm{TA})_{i t} \leq \gamma_{2} \\ \mu_{i}+\theta^{\prime} H_{i t}+\beta_{3}(\mathrm{TD} / \mathrm{TA})_{i t}+\varepsilon_{i t}, & \text { if }(\mathrm{TD} / \mathrm{TA})_{i t}>\gamma_{2}\end{cases}
$$

Where threshold value $\gamma_{1}<\gamma_{2}$. This can be extended to multiple $\left(\gamma_{1}, \gamma_{2}, \gamma_{3}, \ldots, \gamma_{n}\right)$. 


\section{Empirical Results}

\subsection{Descriptive Statistics}

Table 2 represents the descriptive statistics of all variable in this study. Financial information was collected from balance sheets and annual business outcome reports of 90 unlisted Seafood Processing Enterprises in the South Central region of Vietnam during 2005-2011 period.

Results of descriptive statistics in table 2 show that: Firm value by average BVE and ROE of SEASCRs are 22.9077 (equivalent to 32.14 billions VND) and $2.92 \%$. The mean of debt ratio (TD/TA) of SEASCRs is $59.39 \%$. Size by average assets (SIZE) of SEASCRs is 23.7785 (equivalent to 69.86 billions VND). Growth rate of operating sales (SG) of SEASCRs is 5.28\%. Table 2 also includes median value, minimum value, maximum value, standard deviation and no. of observations.

Table 2. Descriptive Statistics

\begin{tabular}{lllllll}
\hline Variables & Observations & Mean & Median & Maximum & Minimum & Std. Dev. \\
\hline BVE $_{\text {it }}$ & 630 & 22.9077 & 22.8343 & 19.7322 & 28.2582 & 1.4824 \\
ROE $_{\text {it }}$ & 630 & 0.0292 & 0.0303 & -1.5442 & 0.8785 & 0.2104 \\
$(\mathrm{TD} / \mathrm{TA})_{\text {it }}$ & 630 & 0.5939 & 0.6397 & 0.0192 & 0.9832 & 0.2326 \\
$\mathrm{SIZE}_{\text {it }}$ & 630 & 23.7785 & 23.7311 & 20.3455 & 28.5690 & 1.5208 \\
$\mathrm{SG}_{\text {it }}$ & 630 & 0.0528 & 0.0832 & -2.3901 & 2.6893 & 0.5033
\end{tabular}

Notes: Std. Dev. denotes standard deviation, $* * *, * *$ and $*$ indicate significance at the $1 \%, 5 \%$ and $10 \%$ level, respectively.

\subsection{Panel unit root test results}

Hansen's (1999) panel threshold regression model is an extension of the traditional least squared estimation method, in fact. It requires that variables considered in the model need to be stationary in order to avoid the so-called spurious regression. Thus, the unit root test is first processed in this study. The null hypothesis of non-stationary versus the alternative in which variable is stationary, was tested using the group mean panel unit root test.

Table 3. Panel unit-root test results

\begin{tabular}{|c|c|c|c|c|}
\hline \multirow{2}{*}{ Variables } & \multicolumn{2}{|c|}{ LLC } & \multicolumn{2}{|c|}{ IPS } \\
\hline & t-statistic & P-value & Z-statistic & $\mathrm{P}$-value \\
\hline $\mathrm{BVE}_{\mathrm{it}}$ & $-21,6564$ & $0.0000 * * *$ & $-3,9952$ & $0.0000 * * *$ \\
\hline $\mathrm{ROE}_{\text {it }}$ & $-9,1806$ & $0.0000 * * *$ & $-5,5745$ & $0.0000^{* * *}$ \\
\hline$(\mathrm{TD} / \mathrm{TA})_{\mathrm{it}}$ & $-18,0200$ & $0.0000 * * *$ & $-2,7747$ & $0.0000 * * *$ \\
\hline $\mathrm{SIZE}_{\text {it }}$ & $-14,2492$ & $0.0000 * * *$ & $-3,9675$ & $0.0000 * * *$ \\
\hline $\mathrm{SG}_{\text {it }}$ & $-20,9811$ & $0.0000 * * *$ & $-7,3985$ & $0.0000 * * *$ \\
\hline
\end{tabular}

Notes: LLC and IPS represent the Levin et al. (2002) and Im et al. (2003) panel unit-root test, respectively. ***, ** and * indicate significance at the $1 \%, 5 \%$ and $10 \%$ level, respectively. 
Table 3 represents the result of Levin et al. (2002) and IPS ADF (Im et al., 2003) and shows that all variables are stationary at level as P-values are indicating the rejection of null hypothesis. Accordingly, the author proceed with full analysis.

\subsection{Tests of threshold effect}

In this study, the author follow the bootstrap method proposed by Hansen (1999) to obtain the approximations of the F statistics and then calculate the p-values. The bootstrap procedure is repeated 1000 times for each of the three panel threshold tests. The F statistics contains F1, F2 and F3 to assess the null hypotheses of none, one and two thresholds, respectively. Table 4 presents the test statistics F1, F2, and F3, along with their bootstrap P-values.

Table 4. Tests for threshold effects between the debt ratio and proxy variables for firm value

\begin{tabular}{|c|c|c|c|c|c|c|c|c|}
\hline \multirow{2}{*}{ Firm value variables } & \multirow{2}{*}{\multicolumn{3}{|c|}{ Threshold value }} & \multicolumn{2}{|c|}{ F-statistic } & \multicolumn{3}{|c|}{ Test critical values } \\
\hline & & & & F-stat & P-value & $1 \%$ & $5 \%$ & $10 \%$ \\
\hline \multicolumn{9}{|c|}{ Single threshold effect test } \\
\hline $\mathrm{BVE}_{\mathrm{it}}$ & 0.6381 & & & 211.30 & $0.00 * * *$ & 24.13 & 15.95 & 13.58 \\
\hline $\mathrm{ROE}_{\mathrm{it}}$ & 0.8998 & & & 35.08 & $0.00 * * *$ & 22.35 & 18.95 & 15.17 \\
\hline \multicolumn{9}{|c|}{ Double threshold effect test } \\
\hline $\mathrm{BVE}_{\mathrm{it}}$ & 0.5739 & 0.7867 & & 97.20 & $0.00 * * *$ & 23.08 & 16.81 & 13.97 \\
\hline $\mathrm{ROE}_{\mathrm{it}}$ & 0.5793 & 0.8998 & & 20.31 & $0.03 * *$ & 24.54 & 15.96 & 13.60 \\
\hline \multicolumn{9}{|c|}{ Triple threshold effect test } \\
\hline $\mathrm{BVE}_{\mathrm{it}}$ & 0.5739 & 0.7867 & 0.9230 & 63.08 & $0.00 * * *$ & 24.08 & 16.18 & 13.46 \\
\hline $\mathrm{ROE}_{\mathrm{it}}$ & 0.5396 & 0.5793 & 0.8998 & 9.97 & 0.19 & 20.08 & 13.50 & 12.03 \\
\hline
\end{tabular}

Notes: $\mathrm{F}$-statistics and $\mathrm{p}$-values are from repeating bootstrap procedures 1000 times for each of the three bootstrap tests. $* * * * *$ and $*$ indicate significance at the 1,5 and $10 \%$ level, respectively.

Results of tests for threshold effects between the debt ratio and proxy variables for firm value in table 4 show that:

Regarding BVE as a proxy for firm value, the single threshold effect is first tested to see if it exists. By using bootstrap to make 1000 times, F-tatistics (F1) of 211.30 and P-value of 0.00 are respectively yielded. They show significance under $1 \%$ significant level and reject the null hypothesis of no threshold effect. Likewise, bootstrap is used to make 1000 times and respectively yields F-statistics (F2) of 97.20 and P-value of 0.00 . They show significance under a 1\% significant level and reject the null hypothesis of one threshold. Finally, triple-threshold effect is tested to see if it exists. Similarly, bootstrap is used to make 1000 times and respective yields F-statistics (F3) of 63.08 and Pvalue of 0.00 . The results reject the null hypothesis of two thresholds, suggesting the possibility of three thresholds. In conclusion, the aforementioned statistic analysis articulately shows that an asymmetric relationship of three thresholds in four regimes is significantly formed. Table 4 also presents the estimated values of three thresholds, which are $57.39 \%, 78.67 \%$ and $92.30 \%$, respectively. All observations are objectively and passively split into four regimes depending on whether the threshold variable it (TD/TA) it is smaller or larger than the threshold value $\left(\hat{\gamma}_{1}, \hat{\gamma}_{2}, \hat{\gamma}_{3}\right)$. Accordingly, the author define four regimes formed by three threshold values to be low debt, medium debt, high debt 
and very high debt if their debt ratio within the ranges $(0.00 \%-57.39 \%),(57.39 \%-78.67 \%),(78.67 \%-92.30 \%)$ and exceed $92.30 \%$. The figure of appendix 1 shows the confidence interval construction in single threshold, double threshold and triple threshold.

Regarding ROE as proxy of firm value, the single threshold effect is first tested to see if it exists. By using bootstrap to make 1000 times, F-tatistics (F1) of 35.08 and P-value of 0.00 are respectively yielded. They show significance under 1\% significant level and reject the null hypothesis of no threshold effect. Likewise, bootstrap is used to make 1000 times and respectively yields F-statistics (F2) of 20.31 and P-value of 0.03 . They show significance under a 5\% significant level and reject the null hypothesis of one threshold. Finally, triple-threshold effect is tested to see if it exists. Similarly, bootstrap is used to make 1000 times and respective yields F-statistics (F3) of 9.97 and P-value of 0.19. The results reject the null hypothesis of three thresholds. In conclusion, the aforementioned statistic analysis articulately shows that an asymmetric relationship of two thresholds in three regimes is significantly formed. Table 4 also presents the estimated values of two thresholds, which are $57.93 \%$ and $89.98 \%$, respectively. All observations are objectively and passively split into three regimes depending on whether the threshold variable it (TD/TA) it is smaller or larger than the threshold value $\left(\hat{\gamma}_{1}, \hat{\gamma}_{2}\right)$. Accordingly, the author define three regimes formed by two threshold values to be debt if their debt ratio within the ranges $(0.00 \%-57.93 \%),(57.93 \%-89.98 \%)$ and exceed $89.98 \%$. The figure of appendix 2 shows the confidence interval construction in single threshold, double threshold.

Table 5. Estimated coefficients of firm value for each proxy variable for the firm value

\begin{tabular}{lllllll}
\hline Firm value variables & Coefficients & Estimated value & OLS SE & White SE & toLS & $\mathrm{t}_{\text {White }}$ \\
\hline \multirow{3}{*}{$\mathrm{BVE}_{\text {it }}$} & $\hat{\beta}_{1}$ & 0.2963 & 0.1053 & 0.1085 & $2.8139^{* * *}$ & $2.7309^{* * *}$ \\
& $\hat{\beta}_{2}$ & -0.4109 & 0.0971 & 0.0980 & $-4.2317^{* * *}$ & $-4.1929^{* * *}$ \\
& $\hat{\beta}_{3}$ & -0.9661 & 0.1013 & 0.1070 & $-9.5370^{* * *}$ & $-9.0290^{* * *}$ \\
& $\hat{\beta}_{4}$ & -1.6929 & 0.1413 & 0.1906 & $-11.9809^{* * *}$ & $-8.8820^{* * *}$ \\
\hline \multirow{2}{*}{$\mathrm{ROE}_{\text {it }}$} & $\hat{\beta}_{1}$ & 0.1488 & 0.0686 & 0.0745 & $2.1691^{* *}$ & $1.9978^{* *}$ \\
& $\hat{\beta}_{2}$ & -0.0043 & 0.0624 & 0.0591 & -0.0692 & -0.0731 \\
& $\hat{\beta}_{3}$ & -0.3128 & 0.0841 & 0.1176 & $-3.7185^{* * *}$ & $-2.6606^{* * *}$ \\
\hline
\end{tabular}

Notes: $\hat{\beta}_{1}, \hat{\beta}_{2}, \hat{\beta}_{3}$ are the coefficient estimates that are smaller and larger than the threshold value $\gamma$. OLS SE and White SE represent conventional OLS SEs (considering homoscedasticity) and White-corrected SEs (considering heteroscedasticity), respectively. ***,** and * indicate significance at the 1,5 and $10 \%$ level, respectively.

Table 5 shows the estimated coefficients, conventional OLS standard errors, and White-corrected standard errors for each proxy variable for the firm value. The results in table 5 show that:

Regarding BVE as a proxy for firm value, in the first regime when debt ratio is less than $57.39 \%$, the estimated coefficient of BVE $\left(\hat{\beta}_{1}=0.2963\right)$ is positive and significant at the $1 \%$ level, indicating that BVE increases by $0.2963 \%$ with an increase of $1 \%$ in debt ratio. The negative effects of debt on firm value are found in the second, third and last regime, respectively. In the second regime, where the debt ratio is between $57.39 \%$ and $78.67 \%$, the estimated coefficient of BVE $\left(\hat{\beta}_{2}=-0.4109\right)$ is negative and significant at the $1 \%$ level, indicating that BVE decreases by 
$0.4109 \%$ with an increase of $1 \%$ in debt ratio. In the third regime, where the debt ratio is between $78.67 \%$ and $92.30 \%$, the estimated coefficient of BVE $\left(\hat{\beta}_{3}=-0.9661\right)$ is negative and significant at the $1 \%$ level, indicating that BVE decreases by $0.9661 \%$ with an increase of $1 \%$ in debt ratio. In the last regime, where the debt ratio is greater than $92.30 \%$, the estimated coefficient of $\operatorname{BVE}\left(\hat{\beta}_{4}=-1.6929\right)$ is negative and significant at the $1 \%$ level, indicating that BVE decreases by $1.6929 \%$ with an increase of $1 \%$ in debt ratio.

Regarding ROE as a proxy for firm value, in the first regime when debt ratio is less than $57.93 \%$, the estimated coefficient of BVE $\left(\hat{\beta}_{1}=0.1488\right)$ is positive and significant at the $5 \%$ level, indicating that ROE increases by $0.1488 \%$ with an increase of $1 \%$ in debt ratio. The negative effects of debt on firm value are found in the second and last regime, respectively. In the second regime, where the debt ratio is between $57.93 \%$ and $89.98 \%$, the estimated coefficient of $\operatorname{ROE}\left(\hat{\beta}_{2}=-0.0043\right)$ is negative and insignificant, indicating that there is no relationship between debt ratio and firm value. In the third regime, where the debt ratio is greater than $89.98 \%$, the estimated coefficient of ROE $\left(\hat{\beta}_{3}=-0.3128\right)$ is negative and significant at the $1 \%$ level, indicating that ROE decreases by $0.3128 \%$ with an increase of $1 \%$ in debt ratio.

Therefore, the results clearly suggest that the relationship between debt ratio and firm value (that is, the slope value) varies in accordance with different changes in debt structure, and that debt structure has a nonlinear relationship with firm value.

Table 6. Estimated coefficients of control variables for each proxy variable for the firm value

\begin{tabular}{lllllll}
\hline Firm value variables & Coefficients & Estimated value & OLS SE & White SE & $\mathrm{t}_{\text {OLS }}$ & $\mathrm{t}_{\text {White }}$ \\
\hline BVE $_{\text {it }}$ & $\hat{\theta}_{1}$ & 0.9834 & 0.0261 & 0.0339 & $37.6782^{* * *}$ & $29.0088^{* * *}$ \\
& $\hat{\theta}_{2}$ & 0.0017 & 0.0231 & 0.0242 & 0.0736 & 0.0702 \\
\hline $\mathrm{ROE}_{\text {it }}$ & $\hat{\theta}_{1}$ & 0.0259 & 0.0171 & 0.0148 & 1.5174 & $1.7509 *$ \\
& $\hat{\theta}_{2}$ & 0.0189 & 0.0151 & 0.0142 & 1.2492 & 1.3272 \\
\hline
\end{tabular}

Notes: $\hat{\theta}_{1}, \hat{\theta}_{2}$ represent estimated coefficients of firm size, growth rate of operating sales. OLS SE and White SE represent conventional OLS SEs (considering homoscedasticity) and White-corrected SEs (considering heteroscedasticity), respectively. ***,** and * indicate significance at the 1 , 5 and $10 \%$ level, respectively.

Table 6 presents the estimated coefficients of two control variables, conventional OLS standard errors, and Whitecorrected standard errors for each proxy variable for the firm value. The results in table 6 show that:

Regarding BVE as a proxy for firm value, the estimated coefficient of firm size $\left(\hat{\theta}_{1}=0.9834\right)$ is positive and significant at the $1 \%$ level, indicating that BVE increases by $0.9834 \%$ with an increase of $1 \%$ in firm size. The estimated coefficient of growth rate of operating sales $\left(\hat{\theta}_{2}=0.0017\right)$ is positive and is insignificant, indicating that there is no relationship between growth rate of operating sales and firm value.

Regarding ROE as a proxy for firm value, the estimated coefficient of firm size $\left(\hat{\theta}_{1}=0.0259\right)$ is positive and significant at the $10 \%$ level, indicating that ROE increases by $0.0259 \%$ with an increase of $1 \%$ in firm size. The 
estimated coefficient of growth rate of operating sales $\left(\hat{\theta}_{2}=0.0189\right)$ is positive and is insignificant, indicating that there is no relationship between growth rate of operating sales and firm value.

Therefore, the results clearly suggest that, the size of total assets have a significantly positive effect on firm value, implying that the greater the size of total assets, that a firm have, the higher its firm value. Moreover, the growth rate of operating sales are shown to have no significant effect on firm value. This implies that expanding growth rate of operating sales does not necessarily increase firm value.

\subsection{Estimated Model}

Based on empirical findings, following is the estimated model when total debt to total assets (TD/TA) are taken as proxy of capital structure and BVE as a proxy for firm value:

$$
\mathrm{BVE}_{i t}=\left\{\begin{array}{l}
\mu_{i}+0.9834 \mathrm{SIZE}_{i t}+0.0017 \mathrm{SG}_{i t}+0.2963(\mathrm{TD} / \mathrm{TA})_{i t}+\varepsilon_{i t}, \text { if }(\mathrm{TD} / \mathrm{TA})_{i t} \leq 0.5739 \\
\mu_{i}+0.9834 \mathrm{SIZE}_{i t}+0.0017 \mathrm{SG}_{i t}-0.4109(\mathrm{TD} / \mathrm{TA})_{i t}+\varepsilon_{i t}, \text { if } 0.5739<(\mathrm{TD} / \mathrm{TA})_{i t} \leq 0.7867 \\
\mu_{i}+0.9834 \mathrm{SIZE}_{i t}+0.0017 \mathrm{SG}_{i t}-0.9661(\mathrm{TD} / \mathrm{TA})_{i t}+\varepsilon_{i t}, \text { if } 0.7867<(\mathrm{TD} / \mathrm{TA})_{i t} \leq 0.9230 \\
\mu_{i}+0.9834 \mathrm{SIZE}_{i t}+0.0017 \mathrm{SG}_{i t}-1.6929(\mathrm{TD} / \mathrm{TA})_{i t}+\varepsilon_{i t}, \text { if }(\mathrm{TD} / \mathrm{TA})_{i t}>0.9230
\end{array}\right.
$$

The empirical results strongly indicate that triple threshold effect exists between debt ratio and firm value when BVE is selected to proxy firm value. Besides, the coefficient is positive when debt ratio is less than $57.39 \%$, which implies that debt financing can improve firm value. The coefficient is negative and presents a decreasing trend when the debt ratio is between $57.39 \%$ and $78,67 \%$ or between $78.67 \%$ and $92.30 \%$ or above $92.30 \%$, implying that, in that regime, a further increase in debt financing, deteriorates firm value.

Following is the estimated model when total debt to total assets (TD/TA) are taken as proxy of capital structure and ROE as a proxy for firm value:

$$
\operatorname{ROE}_{i t}= \begin{cases}\mu_{i}+0.0259 \mathrm{SIZE}_{i t}+0.0189 \mathrm{SG}_{i t}+0.1488(\mathrm{TD} / \mathrm{TA})_{i t}+\varepsilon_{i t}, & \text { if }(\mathrm{TD} / \mathrm{TA})_{i t} \leq 0.5793 \\ \mu_{i}+0.0259 \mathrm{SIZE}_{i t}+0.0189 \mathrm{SG}_{i t}-0.0043(\mathrm{TD} / \mathrm{TA})_{i t}+\varepsilon_{i t}, & \text { if } 0.5793<(\mathrm{TD} / \mathrm{TA})_{i t} \leq 0.8998 \\ \mu_{i}+0.0259 \mathrm{SIZE}_{i t}+0.0189 \mathrm{SG}_{i t}-0.3128(\mathrm{TD} / \mathrm{TA})_{i t}+\varepsilon_{i t}, & \text { if }(\mathrm{TD} / \mathrm{TA})_{i t}>0.8998\end{cases}
$$

When ROE is selected to proxy firm value, the result shows that there exists double thresholds effect between debt ratio and firm value. Besides, the coefficient is positive when debt ratio is less than $57.93 \%$, which implies that debt financing can improve firm value. The coefficient is negative and presents a decreasing trend when the debt ratio is between $57.93 \%$ and $89.98 \%$ or above $89.98 \%$, implying that, in that regime, a further increase in debt financing, deteriorates firm value.

From the above results, the author may conclude that the relationship between capital structure and firm value has a nonlinear relationship represents an convex Parapol shape. In addition, it is concluded that there exists an optimal debt ratio is less than $57.39 \%$ that increases firm value. These findings are consistent with the trade-off theory (Myers, 1977), Chien-Chung Nieh et al. (2008), Yu-Shu Cheng et al. (2010), Cuong and Canh (2012), Ahmad and Abdullah (2013) for which firm may search a "balance" that the interest tax shield is equal to the incremental costs through debt financing. The size of total assets have a significantly positive effect on firm value, implying that the greater the size 
of total assets, that a firm have, the higher its firm value. However, the growth rate of operating sales are shown to have no significant effect on firm value. This implies that expanding growth rate of operating sales does not necessarily increase firm value.

\section{Conclusions and Implications}

The capital structure decision is crucial for any business organization. The decision is important because of the need to maximize returns to various organizational constituencies, and also because of the impact such a decision has on an organization's ability to deal with its competitive environment. This study uses the advanced panel threshold regression model to examine the panel threshold effect of capital structure on firm value among 90 unlisted Seafood Processing Enterprises in the South Central region of Vietnam during 2005-2011 period. The findings of the study shows the presence of triple threshold effect of debt ratio on firm value when BVE is selected to proxy firm value. However, when ROE is selected to proxy firm value, the result shows that there exists double thresholds effect between debt ratio and firm value. From these results, the author may conclude that the relationship between capital structure and firm value has a nonlinear relationship represents an convex Parapol shape. In addition, this study provides new evidence on the existence of threshold debt ratio of $57.39 \%$ for unlisted Seafood Processing Enterprises in the South Central region of Vietnam. This result supports the trade-off theory and the findings of previous authors, also as author's hypothesis in this study, implying that there exists an optimal capital structure for each enterprise. For the control variables, according to empirical results, the size of total assets have a significantly positive effect on firm value. This finding supports author's hypothesis in this study, implying that the greater the size of total assets, that a firm have, the higher its firm value. However, the growth rate of operating sales are shown to have no significant effect on firm value. This finding not supports author's hypothesis in this study, implying that expanding growth rate of operating sales does not necessarily increase firm value.

From the above mentioned findings, there will be several implications for Seafood Processing Enterprises in the South Central region of Vietnam in using financial leverage. Firstly, SEASCRs should not use loans over 57.39\%. To ensure and enhance the firm value, the scope of the optimal debt ratio should be less than 57.39\%. Secondly, for SEASCRs currently have debt ratios greater than $57.39 \%$, managers can apply the models that are developed here in order to set a target level, and then gradually move towards it so as to maximize firm value. Thirdly, the firms using debt below optimal range may employ more debt to get the benefits of tax shield that increases the firm value.

Financial statements of most unlisted Seafood Processing Enterprises in the South Central region of Vietnam are not audited. The availability and reliability of financial data was a major limitation for this research. Therefore, the enterprise value is not measured by the market value. In the future, the enterprise value will be measured by market value. Future research could also consider the effect of specific industries, ownership and market variables, with the aim of examining the effect of such variables on the firm's value in Vietnam. 


\section{References}

Abdul Ghafoor Khan (2012), "The relationship of capital structure decisions with firm performance: A study of the engineering sector of Pakistan”, International Journal of Accounting and Financial Reporting, Vol. 2, No. 1 (2012), pp. 245-262.

Ahmad, A. H., \& Abdullah, N. A. H. (2013). Investigation of optimal capital structure in Malaysia: a panel threshold estimation. Studies in economics and finance, 30(2), 108 - 117.

Ali Saeedi and Iman Mahmoodi (2011), "Capital Structure and Firm Performance: Evidence from Iranian Companies", International Research Journal of Finance and Economics, Issue 70 (2011), pp. 20-29.

Chien-Chung Nieh, Hwey-Yun Yau, and Wen-Chien Liu(2008), "Investigation of Target Capital Structure for Electronic Listed Firms in Taiwan”, Emerging Markets Finance \& Trade 2008, Vol. 44, No. 4, pp. $75-87$.

Cuong, Nguyen Thanh \& Canh, Nguyen Thi (2012), “The Effect of Capital Structure on Firm Value for Vietnam's Seafood Processing Enterprises", International Research Journal of Finance and Economics, Issue 89 (2012), pp. 221-223.

Hansen BE (1999), "Threshold effects in non-dynamic panels: Estimation, testing and inference", Journal of Econometrics 93 (1999), pp.345-368 .

Im, K., Pesaran, M. and Shin, Y. (2003). "Testing for unit roots in heterogeneous panels", Journal of Econometrics 115: 53-74.

Joshua Abor (2005), "The effect of capital structure on profitability: an empirical analysis of listed firms in Ghama". Journal of Risk Finance, Vol.6 No. 5, 2005, pp. 438-445.

Levin, A., Lin, C. and Chu, C. (2002). "Unit root tests in panel data: Asymptotic and finite-sample properties", Journal of Econometrics Vol.108, pp.1-24.

Modigliani, F. and M. Miller (1958), "The cost of capital, corporate finance, and the theory of investment", The American Economic Review 48(3), pp.291-297.

Modigliani, F. and Miller, M. (1963), "Corporate income taxes and the cost of capital: a correction”, The American Economic Review, Vol. 53, 1963, pp. 443-53.

Miller MH (1977), “Debt and taxes”. Journal of Financial, Vol 32(2), pp. 261-275.

Myers SC (1977), “Determinants of corporate borrowing”, Journal of Financial Economics, Vol 5, pp.147-75.

Myers SC (1984), “The capital structure puzzle”, Journal of Finance, Vol.39, pp.575-592.

Myers SC, Majluf, NS (1984), "Corporate financing and investment decisions when firms have information that investors do not have", Journal of Financial Economics, Vol.3 No.2, 1984, pp. 187-222.

Nour Abu-Rub (2012), "Capital Structure and Firm Performance; Evidence from Palestine Stock Exchange”, Journal of Money, Investment and Banking, Issue 23 (2012), pp. 109-117.

Onaolapo and Kajola (2010), “Capital Structure and Firm Performance: Evidence from Nigeria”, European Journal of Economics, Finance and Administrative Sciences, Issue 25 (2010), pp.70-82.

OGBULU, Onyemachi Maxwell, EMENI, Francis Kehinde (2012), "Capital Structure and Firm Value: Empirical Evidence from Nigeria", International Journal of Business and Social Science Vol. 3 No. 19; October 2012. 
Phillips, P. A. \& Sipahioglu (2004), "Performance implications of capital structure: evidence from quoted UK organisations with hotel interests", Service Industries Journal, vol. 24, no. 5, pp. 31-51.

Pornsit Jiraporn and Yixin Liu (2008), "Capital Structure, Staggered Boards, and Firm Value”. Financial Analysts Journal 2008, Vol. 64, No. 1.

Samuel Antwi, Ebenezer Fiifi Emire Atta Mills, Xicang Zhao (2012), "Capital Structure and Firm Value: Empirical Evidence from Ghana", International Journal of Business and Social Science Vol. 3 No. 22 [Special Issue - November 2012].

R. Zeitun, G.G.Tian (2007), "Capital structure and corporate performance: evidence from Jordan", The Australasian Accounting Business \& Finance Journal, Vol. 1, No. 4, (December, 2007), pp. 40-61.

Yu-Shu Cheng, Yi-Pei Liu and Chu-Yang Chien (2010), "Capital structure and firm value in China: A panel threshold regression analysis", African Journal of Business Management Vol. 4(12), pp. 2500-2507, 18 September, 2010, pp. 2500-2507.

Zuraidah Ahmad et al. (2012), "Capital Structure Effect on Firms Performance: Focusing on Consumers and Industrials Sectors on Malaysian Firms", International Review of Business Research Papers Vol. 8. No.5. July 2012. Pp. $137-15$.

Walaa Wahid ElKelish (2007), "Financial structure and firm value: empirical evidence from the United Arab Emirates", International Journal of Business Research 2007, Vol VII, pp.69-76.

Wenjuan Ruan et al. (2011), "Managerial Ownership, Capital Structure and Firm Value: Evidence from China's Civilian-run Firms", Australasian Accounting Business and Finance Journal, 5(3), 2011, 73-92. 
Appendix 1. Tests for threshold effects between capital structure (TD/TA) and firm value (BVE)
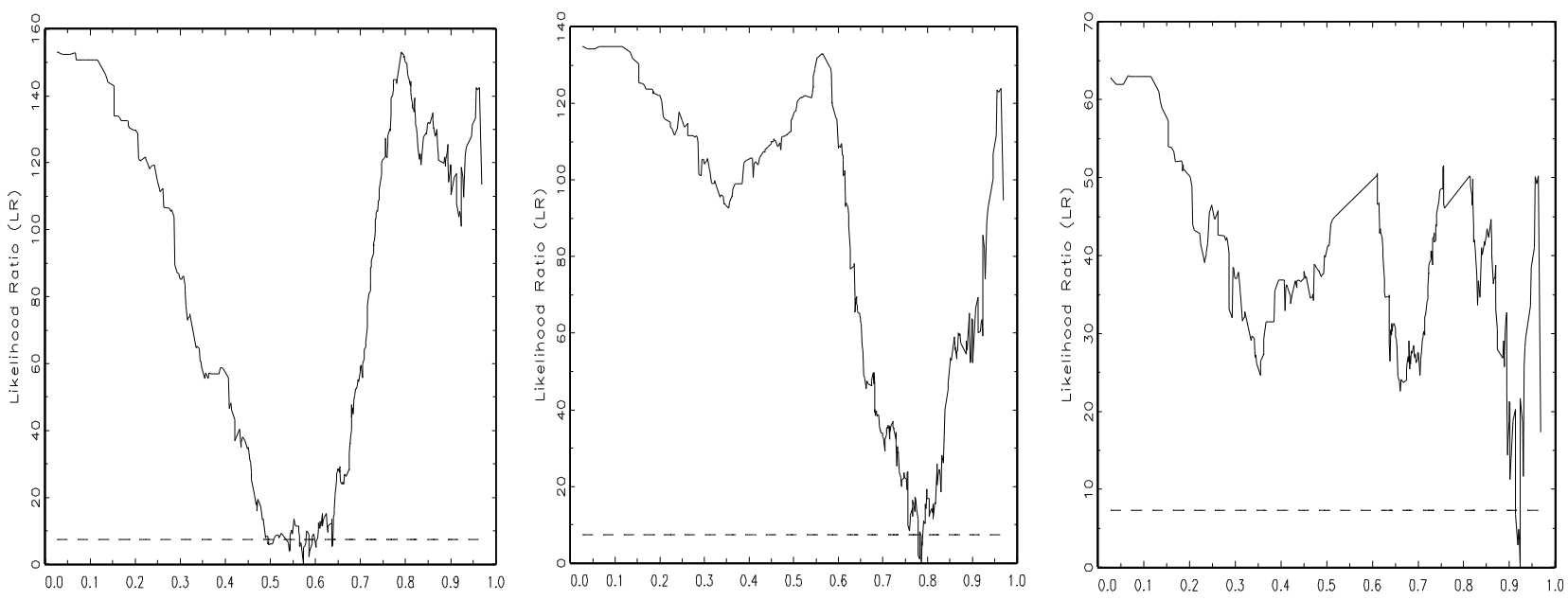

Appendix 2. Tests for threshold effects between capital structure (TD/TA) and firm value (ROE)
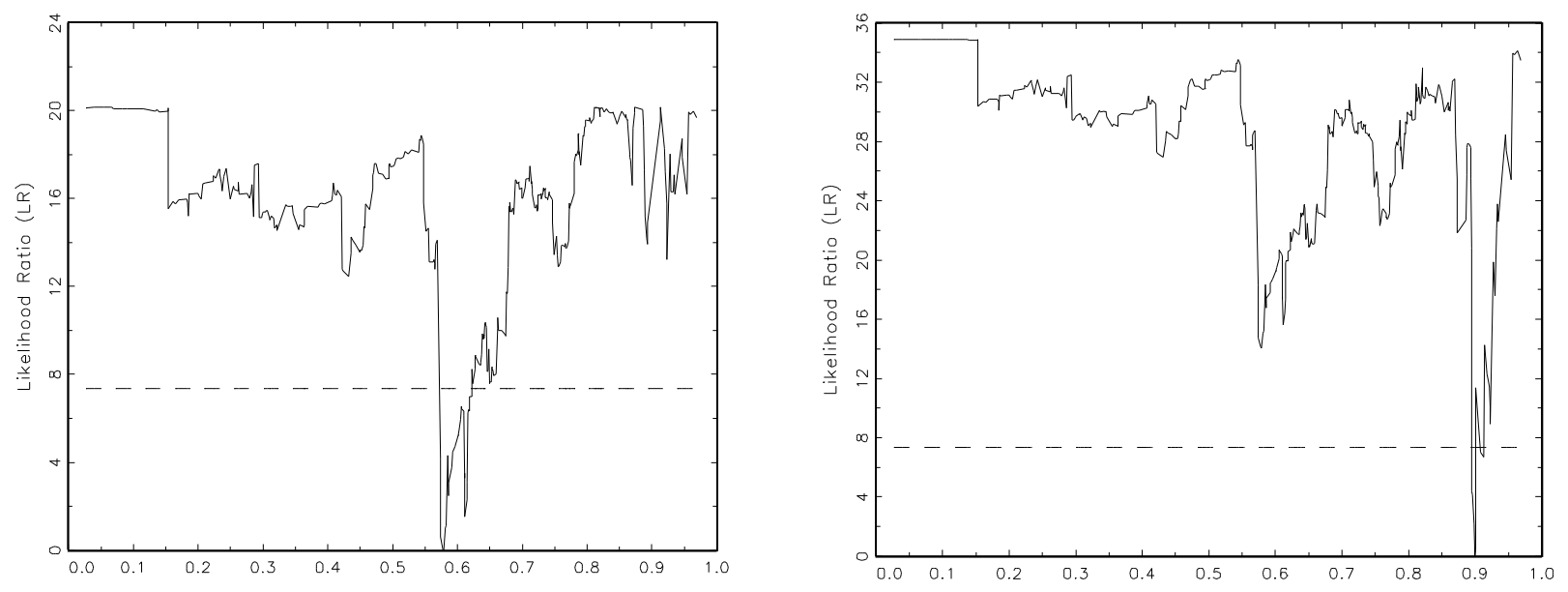